\title{
Társadalmi és gazdasági tényezők hatása a Kassai kerület munkanélküliségének alakulására 1993-tól napjainkig
}

\section{The impact of social and economic factors on unemployment in the Košice region from 1993 to the present}

\author{
KARÁCSONY PÉTER, BÁLINT FLÓRA
}

KARÁCSONY Péter: egyetemi docens, Selye János Egyetem, Gazdaságtudományi Kar, Közgazdaságtani Tanszék; Bratislavská cesta 3322, P.O.Box 54, 94501 Komárno, Szlovákia; karacsonyp@ujs.sk

BÁLINT Flóra: MSc. szakos egyetemi hallgató, Selye János Egyetem, Gazdaságtudományi Kar; Bratislavská cesta 3322, P.O.Box 54, 94501 Komárno, Szlovákia; 3062521645@selyeuni.sk

KULCSSZAVAK: munkanélküliségi ráta, rendszerváltás, Kassai kerület, munkaerőpiac

ABSZTRAKT: Szlovákia különböző térségei más-más helyzetből indulva eltérően reagáltak a piacgazdasági átmenet kihívásaira. Társadalmi-gazdasági egyenlőtlenségek alakultak ki, éles határ húzódik a keleti és a nyugati országrész között. A kilencvenes évek társadalmi-gazdasági folyamatainak egyik meghatározó eleme volt a tömeges és tartós munkanélküliség.

A tanulmány célja, hogy bemutassuk a munkanélküliség alakulását a Kassai kerületben a szlovák államalapítástól napjainkig. Tanulmányunk kiemelten foglalkozik azokkal a kormányzati intézkedésekkel, amelyeket a munkaerő-piaci körülmények változtatásának érdekében tettek.

A következő megállapítások vonhatók le röviden: a Kassai kerületben kialakult előnytelen munkaerő-piaci helyzet az átgondolatlan rendszerváltás és az egyes szlovákiai kormányok intézkedéseinek negatív „mellékterméke”. Napjainkban a munkanélküliség súlyos problémának számít, elengedhetetlen a különböző gazdasági és társadalmi eszközökkel, aktív munkaerő-piaci politikával történő beavatkozás.

Péter KARÁCSONY: associate professor, Faculty of Economics, János Selye University; Bratislavská cesta 3322, P.0.Box 54, 94501 Komárno, Slovakia; karacsonyp@ujs.sk

Flóra BÁLINT: MSc. student, Faculty of Economics, János Selye University; Bratislavská cesta 3322, P.O.Box 54, 94501 Komárno, Slovakia; 3062521645@selyeuni.sk

KEYWORDS: unemployment rate, change of the political system, Košice region, labour market

ABSTRACT: A problem in the Slovak labour market is a long-term high imbalance of labour supply and the demand for labour. Since 1990, a high level of unemployment has persisted which is aggravated by a high rate of long-term unemployment. From a regional perspective, unemployment is concentrated in eastern and south central Slovakia. These regions in Slovakia

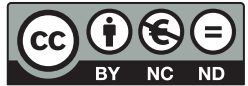


are handicapped by their low-quality infrastructure as well as low economic potential and an unfavourable demographic mix. The aim of this study is to present the development of unemployment in the Košice region from the establishment of an independent Slovak state to the present day.

The transformation of the industrial structure (concerning mainly sectors and ownership) after the change of the political system resulted in high unemployment - which is particularly true for the Košice region. Besides secondary analyses, the empirical part of the paper deals with the evaluation of the effectiveness and impact of specific measures each Slovak government took to develop regional labour markets. Our study findings were as follows: The unfavourable position of the Košice region in the Slovak labour market is a by-product of bad governmental decisions and of the Slovak transition to a market economy. The rising unemployment in the Košice region is a serious economic problem which can be mitigated by various economic and social policies described in the conclusions.

\section{Bevezetés}

Napjainkban a modern piacgazdaságok egyik legnagyobb kihívása a munkanélküliség növekedésének fékentartása. A rendszerváltás után Szlovákiában is megváltoztak a társadalmi-gazdasági folyamatok, tömegesen szűntek meg munkahelyek, egy-egy gazdasági ágazat összeomlásával térségek, települések kerültek nehéz helyzetbe. A szocialista gazdaságokban ismeretlen fogalom volt a munkanélküliség, magas volt a foglalkoztatási ráta, szinte minden dolgozó biztosnak érezhette a munkahelyét. A rendszerváltással jelentős mértékben csökkent a foglalkoztatási ráta és megjelent a nyílt munkanélküliség (Kornai 2005).

A privatizáció következtében megszűnt munkahelyek száma nagyobb mértékű volt a vidéki gyáregységekben, sokszor az egyetlen munkalehetőség tűnt el, így ezrek kerültek egyik napról a másikra az utcára. A vidéki térségekben tovább súlyosbította a helyzetet, hogy a jelentős foglalkoztatottságot biztosító nagyüzemi mezőgazdaság és a hozzá kapcsolódó melléküzemági tevékenységek is átalakultak. Szlovákiában 1990 után jelentősen megnőtt a magánszférában foglalkoztatottak száma, 1995-ben már kevesebben dolgoztak az állami szférában, mint a magánszférában. (1. ábra)

A visegrádi együttműködés országainak munkanélküliségi mutatói a rendszerváltást követően eltérő folyamatokra utalnak. Szlovákiában és Lengyelországban 1991-re a munkanélküliségi ráta elérte a 11,8 és 12,2 százalékot, míg Magyarország és Csehország helyzete kedvezőbb volt (1. táblázat). Vagyis a legnagyobb veszteséget a szlovák és lengyel dolgozók szenvedték el a rendszerváltás során, sőt e két országban a munkanélküliségi ráta tartósan magas maradt. Véleményünk szerint a növekvő munkanélküliség okai a gyors és átgondolatlan rendszerváltásban, a Csehszlovákia szétválásával megörökölt elavult szlovák ipari struktúrában, valamint a rendszerváltozást követő kezdeti időszakban a munkanélküli és szociális segélyek túlzott mértékében keresendők.

Csehszlovákia esetében a rendszerváltozás időigényesebb folyamat volt, mint ahogy azt az ország akkori vezetői képzelték. Ezen időszakra sokan a gaz- 
1. ábra: A foglalkoztatottak számának alakulása a rendszerváltás után Szlovákiában (ezer fö) Changes in employment after 1990 in Slovakia (in thousands)

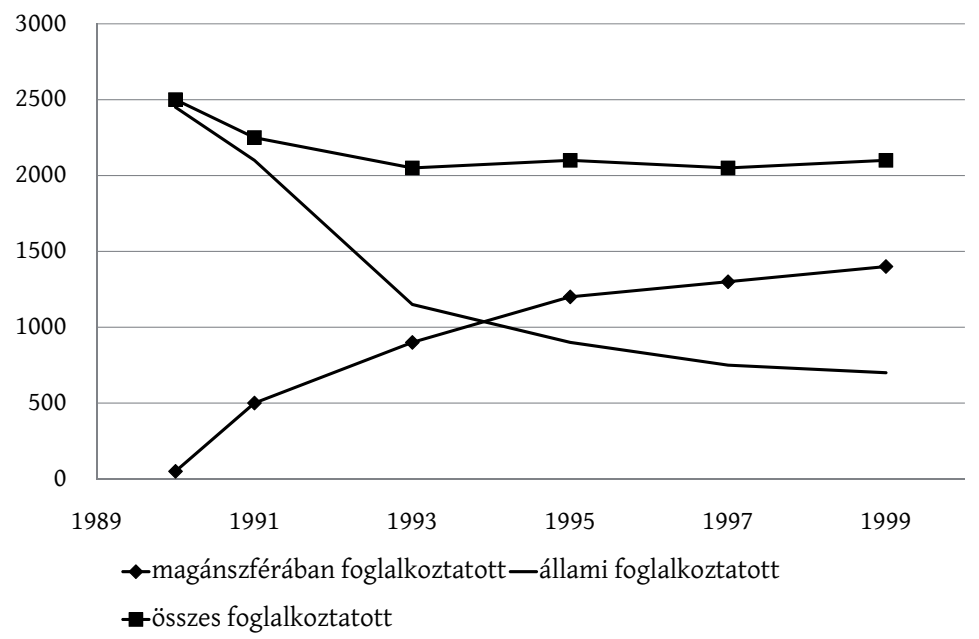

Adatok forrása: Rievajová, Pongráczová 2007.

dasági visszaesés korszakaként tekintenek vissza (Nižňanský, Reptová 1999). Csehszlovákiában egészen a rendszerváltozásig merev formában megmaradt a központi tervutasításos rendszer. Nem lazult fel a szocialista tervgazdaság, mint például Magyarországon (Morvay 2005).

Szlovákiában a privatizáció folyamata több, egymástól jól elkülöníthető szakaszra osztható. 1991 és 1993 között jórészt a kisebb állami kereskedelmi, idegenforgalmi és szolgáltató vállalatokat privatizálták. Ez az időszak a kisléptékủ privatizáció elnevezést kapta. A privatizáció második szakasza az úgynevezett nagyléptékủ privatizáció, melynek első - 1992 végéig tartó - fázisában a kuponos privatizáció forgatókönyvét valósították meg. Az alapgondolat az volt, hogy a részvénytársaságokká alakított állami vállalatok részvényeit úgynevezett befektetési kuponok ellenében vásárolhatják meg az érdeklődők. A kuponos privatizációval a tőkehiány problémáját kívánták áthidalni (Tř́iska 2002). A

1. táblázat: A munkanélküliségi ráta alakulása a visegrádi együttműködés országaiban, 1990 és 1995 között (\%)

Unemployment of the Visegrad Group 1990-1995 (in \%)

\begin{tabular}{lrrrrrr}
\hline \multicolumn{1}{c}{ Ország } & 1990 & 1991 & 1992 & 1993 & 1994 & 1995 \\
\hline Csehország & 0,7 & 4,1 & 2,6 & 3,5 & 3,2 & 2,9 \\
Szlovákia & 1,6 & 11,8 & 10,4 & 14,4 & 14,8 & 13,1 \\
Magyarország & 1,7 & 7,4 & 12,3 & 12,1 & 10,9 & 10,4 \\
Lengyelország & 6,5 & 12,2 & 14,3 & 16,4 & 16,0 & 14,9 \\
\hline
\end{tabular}

Forrás: saját szerkesztés az UNECE statisztikai adatbázisa alapján. 
nagyléptékű privatizáció második hulláma 1993 szeptemberében kezdődött, 1997-ben már magánkézben volt a vállalatok 96,8\%-a. A kuponos privatizáció helyett ebben a szakaszban a hagyományos készpénzes privatizációt és a kötvényes privatizációt alkalmazták. A nagyléptékű privatizáció harmadik fázisát egy 1999-es törvénymódosítás indította el, amely lehetővé tette a korábban stratégiai fontosságúnak ítélt vállalatok privatizációját. Míg korábban a külföldi befektetők távol maradtak, addig a nagyléptékü privatizáció során a bank- és energiaszektor iránti külföldi érdeklődés már jelentőssé vált (Mihalik et al. 1994).

A kelet-szlovákiai régióban végbemenő privatizációs folyamat következményei a következő okokra vezethető vissza (Reiter, Semsey, Tóth 2004):

- A kisebb állami iparvállalatok politikai érdekcsoportok kezébe kerültek. A tranzakciós folyamatok eredménye több esetben a vállalatok elszegényedéséhez és a munkaerő nagyarányú leépítéséhez vezetett.

- A nyugati know-how és a külföldi tőke bevonása a kelet-szlovákiai régió esetében nem volt számottevő a rendszerváltás utáni időszakban.

- A pozsonyi székhelyű nagyvállalatok és leányvállalataik privatizációja során az új tulajdonosok jelentős mértékben építették le a vidéki, így a kelet-szlovákiai részlegekben dolgozók létszámát is.

- A Kelet-szlovákiai Vasmü - amely a Kassai kerület egyik legnagyobb vállalata volt - átgondolatlan privatizációja két szakaszban valósult meg. Az első szakaszban - a Mečiar-kormány idején - a részvények többségét a Rezes Sándor vezette tőkecsoport vette meg, egyidőben a diósgyőri acélművekkel. A vasmű eladósodása miatt a gyár fő üzemegységeit 2000-ben a Dzurinda-kormány a U.S. Steel amerikai nagyvállalatnak adta el. A vállalatcsoport egyes részlegei és az ingatlanok jelentős része kétes hírü szlovák pénzügyi csoportok tulajdonába került (Reiter, Semsey, Tóth 2004). A Kassai Vasmü sikertelen privatizációja azért is volt problematikus, mert a Kassai kerület iparában dolgozók majdnem egyharmada a kohászatban volt alkalmazott a privatizációt megelőző időszakban.

\section{A Kassai kerület általános helyzete}

1996-ban Szlovákiát 8 államigazgatási középszintű egységre osztották fel: a Pozsonyi, Nagyszombati, Nyitrai, Trencséni, Zsolnai, Besztercebányai, Kassai és Eperjesi kerületekre. Ezek a közigazgatási régiók az Európai Unió NUTS 3 szintű egységeinek felelnek meg (Lelkes 2008).

A Szlovákia déli részén fekvő Kassai kerületre az általános elmaradottság a jellemző szlovákiai viszonylatban is. A térség periferikus jellegzetességein kívül ez azzal is magyarázható, hogy az elmúlt évtizedekben - hasonlóan a többi magyarok lakta dél-szlovákiai térséghez - a Kassai kerületet is tudatos politikával hagyták ki a nagyobb fejlesztésekből (Ádám 2004). 
A Kassai kerület területileg Szlovákia negyedik legnagyobb (14,3\%), lakosságszámát tekintve pedig a második legnagyobb (795 565 fö) kerülete. Az iskolázottságot illetően a lakosságon belül dominálnak az alapfokú végzettséggel rendelkezők, míg az egyetemi végzettséggel rendelkezők aránya csupán 14\% körüli, mely országos viszonylatban is a legalacsonyabb. Ezt súlyosbítja az a tény, hogy a diplomás fiatalok körében nagyarányú az elvándorlás. A Kassai kerületben az elmúlt évtizedben a mezőgazdaság szerepe fokozatosan csökkent, az ipari szektorban a rendszerváltás óta elmaradtak a technológiai fejlesztések, a szolgáltatási szektor versenyképessége gyenge.

\section{A kormányzati politika hatása a szlovák munkaerőpiacra}

A független Szlovák Köztársaság 1993. január elsején Csehszlovákia utódállamaként jött létre. A Mečiar vezette első demokratikus kormány idején nagymértékben megváltoztatták a 1990-es évek gazdaságának tulajdonosi szerkezetét. A Mečiar-kormány gazdasági-társadalmi reformja a szlovák társadalom számára egy addig ismeretlen problémát, a munkanélküliséget is magával hozta. Ennek súlyát azzal igyekezett a kormányzat csökkenteni, hogy megnövelte az állam által nyújtott szociális segélyeket. Ez visszafogta a lakosság munkavállalási hajlandóságát, ugyanis a jövedelmi szint és a szociális juttatások közötti különbség nem volt ösztönző hatású a munkakeresésre.

1990 februárjában a szlovák munkaügyi hivatalok 1949 föt regisztráltak munkanélküliként (Rievajová, Krausová 1996), az év végére a regisztrált munkanélküliek száma már elérte a 30000 föt, és 1991-ben már meghaladta a 300000 főt, ami 11,8 \%-os munkanélküliségi rátának felelt meg (Juríčková, Košta 1995). A magas munkanélküliségi ráta Szlovákia esetében tartósnak bizonyult (2. ábra).

Az 1998-ban megtartott parlamenti választások a demokratikus ellenzéki pártok győzelmét hozták. A Dzurinda vezette kormány stabilizációs intézkedései az államháztartás hiányának csökkentését és az államadóság növekedési ütemének visszafogását eredményezték. A költségvetési kiadások visszafogása hatott a munkanélküli támogatások és a szociális segélyek felső határának csökkentésére is (Boros 2000). Dzurinda-kormány által indított szociális változások hozzájárultak a szlovák munkaerő-piaci tendenciák javulásához. A bevezetett aktív munkaerő-piaci politikának (pl. részmunkaidős foglalkoztatás támogatása, képzések ösztönzése, álláskeresés segítése stb.) köszönhetően 2004 utolsó negyedévétől nőtt a foglalkoztatottak száma, mellyel párhuzamosan csökkent az ország munkanélküliségi rátája (19,2\%-ról 13,3\%-ra 2001 és 2006 között). A foglalkoztatás kedvező irányú növekedését ezen időszak alatt több tényező is segítette:

- javult az ország gazdasági helyzete, melynek hatására bővült a foglalkoztatás, 


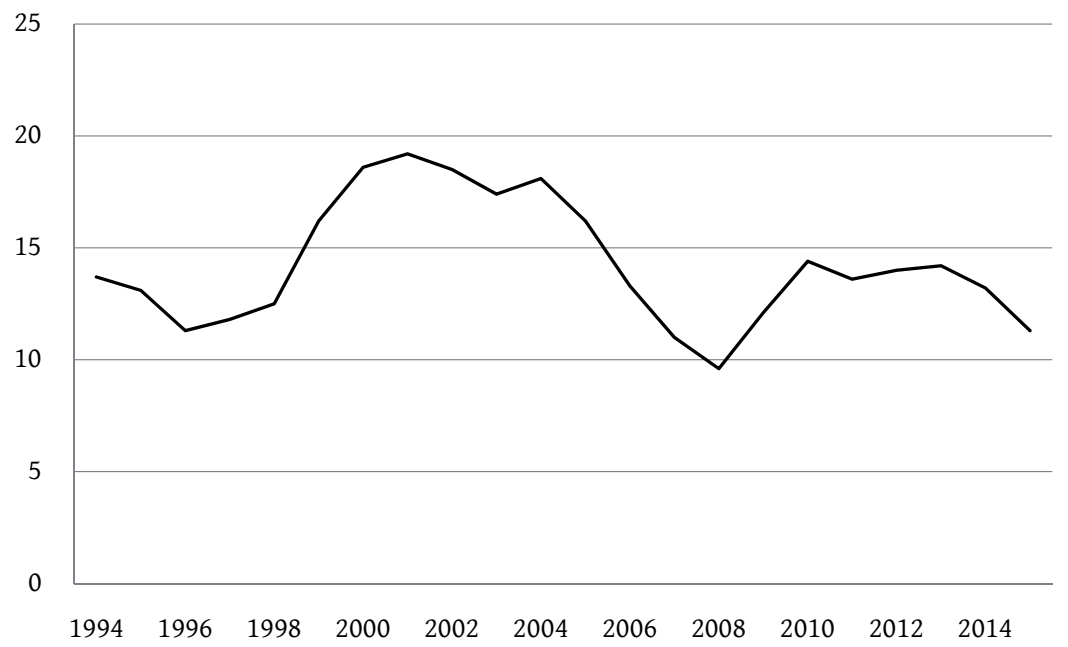

Forrás: saját szerkesztés http://www.statistics.sk/pls/elisw/casovy_Rad.procDlg alapján.

- a kedvezőbb vállalati környezet (adóváltozások) a foglalkoztatás növelésére késztették a vállalkozásokat,

- a 2004-es európai uniós csatlakozás kedvezően befolyásolta Szlovákia külföldi megítélését, ennek köszönhetően közel 30 százalékkal emelkedett az országba érkező külföldi működő tőke,

- az európai uniós csatlakozással megnyílt a lehetőség a szlovákok külföldi munkavállalására.

De ebben az időszakban sem mérséklődtek a régiók közötti különbségek (Klamár 2011). A rendszerváltást követően az egyes kormányok kizárólag részleges megoldásokban gondolkoztak a területi különbségek felszámolásában (Buček 1999; Matlovič, Matlovičová 2011; Mezei, Hardi 2003; Rajčáková, Švecová 2009). A keleti régiók, így a Kassai kerület lemaradásában (3. ábra) szerepet játszott az a tény is, hogy az európai uniós csatlakozást követően a külföldi működő tőke (elsősorban autó- és elektronikai ipari beruházások) Pozsony, Trencsén és Zsolna nagyvárosok vonzáskerületeire összpontosultak (Džupinová et al. 2008).

A 2006 júniusában megtartott parlamenti választások Robert Ficót segítették hatalomra. A Smer vezette koalíció meghirdetett céljai közül kiemelendő a foglalkoztatás szintjének növelése, az életminőség javítása, valamint a regionális különbségek csökkentése. A munkanélküliség terén 2008-ban sikerült pozitív eredményt elérnie a Fico-kormánynak, a munkanélküliségi ráta országos szinten 9,6 \%-ra csökkent, viszont 13\%-os maradt a Kassai kerületben. A 2008-as világgazdasági válság Szlovákia gazdaságát sem kímélte. A külföldi és hazai vállalkozások annak érdekében, hogy mérsékeljék a válság okozta kedvezőtlen 
3. ábra: A munkanélküliségi ráta alakulása Szlovákiában és a Kassai kerületben, 1997-2015 (\%) Unemployment in Slovakia and Košice region, 1997-2015 (in \%)

30

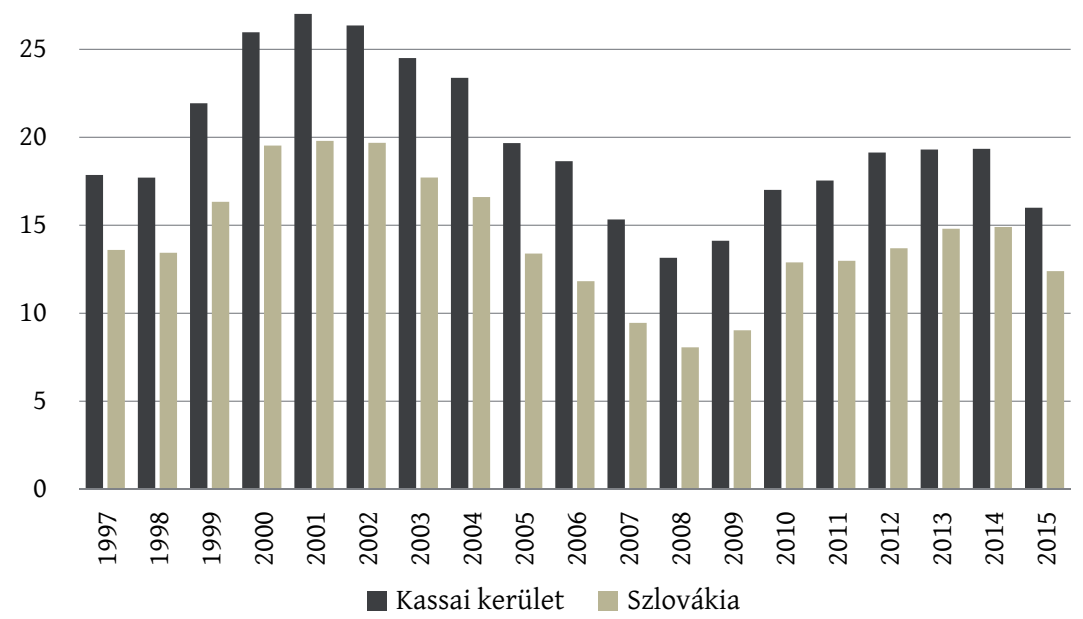

Forrás: saját szerkesztés http://www.upsvar.sk/statistiky/nezamestnanost-mesacne-statistiky adatok alapján.

helyzetüket, a munkavállalók ezreit bocsátották el. Elsősorban a szolgáltatásokban dolgozókat érintette a leépítés, főleg azokban a térségekben, ahol az infrastrukturális ellátás alacsony színvonalú volt. Ilyen veszélyeztetett területnek számított (és számít ma is) a Kassai kerület, ahol a munkanélküliségi ráta jóval az országos átlag felett, 19\% körül alakult a gazdasági válság időszakában.

Robert Fico miniszterelnök saját kormánya munkáját értékelve így fogalmazott: „Szlovákia 2006-ban elhagyta a gyenge állam és az individualizmus elveit, és áttért az erős állam és szolidaritás elveire." Szerinte a megelőző Dzurinda-kormány (1998-2006) idején esett a lakosság életszínvonala, privatizálták az állami vagyont, míg az ő kormányzása (2006-2010) pozitívan hatott az ország gazdasági növekedésére. Az adatok azonban azt mutatták, hogy a Fico-kormány sok időt és pénzt pazarolt el, miközben az ország keleti felében elmaradtak a szükséges és hatékony gazdasági fejlesztések. Ennek eredményeként fokozatosan romlott a keleti kerületek versenyképessége, valamint emelkedett e kerületekben a munkanélküliek aránya.

A 2010-es parlamenti választásokat ugyan ismételten a Robert Fico vezette Smer párt nyerte, de koalíciós partner hiányában nem tudott kormányt alakítani. A jobbközép koalíció vezetője, Iveta Radičova lett a kormányfö, akinek koalíciós kormányába négy jobbközép szlovákiai párt került. A 2010 utáni időszakot újra a gazdasági növekedés jellemezte Szlovákiában, javult az ország külföldi megítélése, ugyanakkor a munkanélküliség visszaszorítása terén e kormány sem büszkélkedhetett sok pozitív eredménnyel: csaknem 140 ezer ember vált munkanélkülivé, a munkanélküliségi ráta 2010-re elérte a 14,4\%-ot. A Radičová-kormány gyors bukása után 2011-ben újra a Robert Fico vezette Irány-Szociálde- 
mokrácia (SMER-SD) párt nyerte a választást. A második Fico-kormány a programjában magasabb szintű foglalkoztatottságot, erőteljes szociális fejlődést, életszínvonal-növekedést, jól múködő oktatásügyi és egészségügyi rendszert, valamint hatékony régiófejlesztést ígért. A gyakorlat azonban mást mutatott: a munka törvénykönyve 2013-as szigorítását, a dolgozók valamennyi kategóriáját sújtó magasabb adók és járulékok bevezetését. A munkanélküliség növekedett, a munkanélküliségi ráta 2014-ben újra elérte a 14\%-ot.

Szlovákiában 2014. július 1-jével lépett érvénybe az a rendelet, mely szerint az anyagi szükséghelyzetben levőknek, tehát a munkanélkülieknek járó 60,50 euró alapsegélyt az állam csak azoknak a szociálisan rászoruló felnőtt személyeknek fizeti ki, akik havonta legalább 32 órát ledolgoznak önkéntes munka vagy más közösségi szolgáltatás terén (ujszo.com 2013). Megítélésünk szerint ez csak látszatfoglalkoztatás, ugyanis ekkora összegből nem lehet Szlovákiában megélni. A 2015-ben bevezetett új rendelet értelmében valamelyest csökkent a munkanélküliek aránya. 2015-ben a munkanélküliségi ráta országos szinten 12,4 \% volt, a Kassai kerületben pedig 16\%-ra mérséklődött a mutató értéke.

Összefoglalva az egyes kormányok munkaerő-piaci intézkedéseit, elmondható, hogy a területi különbségek és a tartós munkanélküliség felszámolásában egyik szlovák kormány sem ért el hosszú távú sikereket. A keleti országrész kerületei a rendszerváltozás óta egyre jobban elmaradnak a nyugati országrésztől, mind a külföldi beruházások, mind az új munkahelyek teremtése terén. A keleti kerületek (köztük a Kassai kerület) munkaerő-piaci mutatói (pl. munkanélküliségi ráta) a globális gazdasági és pénzügyi válság, valamint a szlovák gazdasági növekedés lassulása és teljesítménye miatt 2008-tól fokozatosan romlottak országos összehasonlításban.

\section{A Kassai kerület felzárkózásának gazdasági és társadalmi problémái}

A Kassai kerület az ország egyik leghátrányosabb munkaerő-piaci tendenciáival rendelkezik: a munkanélküliségi ráta a legmagasabb az országban, a nyilvántartott munkanélküliek közel kétharmada tartósan, több mint egy éve állástalan. Ennek demográfiai, szociális és gazdasági okai vannak.

- Demográfiai gondok: A térség egyik legjelentősebb problémájának a lakosság, főként az aktív munkaerő-állomány elvándorlása tekinthető. Mindezek okai a kerület gazdasági elmaradottságában, a munkahelyek hiányában, valamint az alacsony bérekben keresendők. A kelet-szlovákiai térség már a rendszerváltás előtti években is az országon belüli munkaerő-migráció egyértelmű vesztesének számított. Ez a tendencia a 1990-es évek után felerősödött. A térség demográfiai problémája a népesség korösszetételében is kifejeződik: a lakosság elöregedését mutatja, hogy a gazdasá- 
2. táblázat: A munkanélküliségi ráta alakulása a Kassai kerület járásaiban, 2004-2015 (\%) Unemployment rate in districts of Košice region, 2004-2015 (in \%)

\begin{tabular}{lllrrrrrrrrrr}
\hline \multicolumn{1}{c}{ Járás } & 2004 & 2005 & \multicolumn{1}{c}{2006} & \multicolumn{1}{c}{2007} & 2008 & 2009 & 2010 & 2011 & 2012 & 2013 & 2014 & 2015 \\
\hline Gölnicbánya & 26,64 & 22,02 & 21,87 & 17,26 & 16,82 & 17,86 & 20,60 & 20,23 & 21,62 & 24,01 & 24,70 & 18,92 \\
Kassa vidék & 14,28 & 11,40 & 9,93 & 7,29 & 5,86 & 6,19 & 8,00 & 8,60 & 10,01 & 12,01 & 11,49 & 9,48 \\
Kassa I. & 14,67 & 11,84 & 11,36 & 8,92 & 7,44 & 7,68 & 9,85 & 9,79 & 11,11 & 11,59 & 10,60 & 9,19 \\
Kassa II. & 13,82 & 11,59 & 10,45 & 8,08 & 6,56 & 6,35 & 9,27 & 9,11 & 10,46 & 11,53 & 10,55 & 8,52 \\
Kassa III. & 13,79 & 10,68 & 9,31 & 6,74 & 5,39 & 5,90 & 7,92 & 8,32 & 9,77 & 11,53 & 10,45 & 9,28 \\
Kassa IV. & 26,66 & 23,42 & 22,78 & 19,34 & 16,73 & 18,08 & 21,46 & 21,88 & 23,51 & 21,84 & 21,55 & 19,30 \\
Nagymihály & 26,86 & 21,30 & 19,98 & 17,51 & 15,16 & 15,48 & 18,21 & 18,26 & 19,68 & 19,31 & 20,47 & 16,96 \\
Rozsnyó & 30,96 & 26,51 & 25,34 & 22,09 & 20,20 & 22,48 & 26,38 & 27,69 & 28,85 & 29,67 & 29,84 & 23,52 \\
Szobránc & 28,62 & 25,65 & 23,83 & 20,12 & 16,89 & 17,61 & 22,11 & 21,25 & 22,87 & 23,91 & 25,15 & 22,01 \\
Igló & 22,64 & 19,58 & 17,58 & 13,24 & 11,30 & 12,38 & 15,81 & 17,14 & 18,95 & 18,32 & 19,35 & 15,58 \\
Tőketerebes & 30,15 & 26,13 & 25,93 & 22,33 & 18,68 & 21,65 & 24,10 & 25,08 & 27,31 & 24,56 & 25,70 & 20,37 \\
\hline
\end{tabular}

Forrás: saját szerkesztés http://www.upsvar.sk/statistiky/nezamestnanost-mesacne-statistiky adatai alapján.

gilag aktív korban lévő népesség (15-59 éves férfiak, 15-54 éves nők) aránya mélyen országos átlag alatti $(72,3 \%$ az országos átlag, $62,5 \%$ KeletSzlovákiában).

- Szociális problémák: A Kassai kerületben - országos átlagot tekintve - az iskolázottság foka alacsony, mindemellett a felsőfokú végzettséggel rendelkezők körében is magas a munkanélküliségi arány. Ebből is következik a kerület népességének alacsony átlagkeresete, valamint az, hogy a havi átlagkeresetek növekedési dinamikája elmarad az országos átlagtól (Lelkes 2008). A Kassai kerületben élő alapfokú végzettséggel rendelkező munkavállalók havi átlagkeresete 534 euró, az országos átlag 587 euró volt.

- Gazdasági egyenlótlenségek: A Kassai kerületnek az ország gazdasági eredményeihez való hozzájárulása szerény mértékű, az egy före jutó GDP (9 898,32 euró) az országos átlag 77\%-a (Machová et al. 2014). A Kassai kerületen belül is jelentős területi különbségek alakultak ki, a gazdasági teljesítmény túlnyomó része Kassa városában összpontosul, a munkanélküliség területileg differenciálódik. A kassai 10\%-ot megközelítő munkanélküliségi ráta a periferikus térségekben - például a Tőketerebesi, Szobránci vagy Rozsnyói járásban - meghaladja a 20\%-ot. (2. táblázat)

\section{Következtetések, javaslatok}

A szlovák kormányok hosszú távon nem tudtak változtatni sem a munkanélküliség szerkezeti összetételén, sem a munkanélküliség növekvő tendenciáján. Az 1993-tól 1998-ig tartó Mečiar-kormány a hanyagság és az újjáépítési intézkedések szándékos elhalasztásának, a Dzurinda-kormányok a be nem fejezett 
gazdasági átalakulások, a magáncégek kialakulásának és térnyerésének, valamint a magas munkanélküliség kialakulásának időszaka volt. Radičová-kormányt külső és belső viszályok is gyengítették, kevés idő állt rendelkezésre jelentősebb sikerek elérésére. A munkanélküliségi helyzet romlásában a világgazdasági válság mellett jelentős szerepet játszott a Fico-kormányok nem megfelelő gazdaságpolitikája is.

Napjainkban a szlovák gazdaság lassan kezd újra magára találni, ami idővel a szlovák munkanélküliségi arányokat is kedvezően befolyásolhatja. De a Kassai kerület a rendszerváltozás óta gazdasági problémákkal küzd, melynek következtében tartósan magas maradt a munkanélküliség. Ennek okai között kell említeni az infrastrukturális elmaradottságot (mai napig nem épült meg a fővárost Kassával összekötő autópálya), az ipar szerkezeti átalakítása (pl. az acélmüvek privatizációja) következtében fellépő csoportos munkahelybezárásokat, valamint a térség mezőgazdasági szövetkezeteinek drasztikus leépítését.

A Kassai kerület felzárkóztatása érdekében támogató gazdaságpolitikára lenne szükség, új ipari beruházásokra, az idegenforgalom fejlesztésére, az infrastruktúra (elsősorban a közlekedési infrastruktúra) építésére, a külföldi működő tőke vonzására. Nagyobb súlyt kellene fektetni az iskolázottsági szint emelésére, a szakképzésre. A Kassai kerület - kedvező adottságait tekintve - megfelelő gazdaságpolitikával dinamikusabban fejlődhetne.

\section{Irodalom}

Ádám J. I. (2004): A határon túli magyarok részvétele a szlovákiai gazdasági átalakulásban. In: Átalakuló régiók. Dél-Szlovákia és a magyarok által lakott régiók gazdasági helyzete. Európai Összehasonlító Kisebbségkutatások Közalapítvány. Budapest, 9-21. (Műhelytanulmány; 10.)

Boros F. (2000): Szomszédunk, Szlovákia (1993-1999). A diplomata-történész szemével. Kalligram Könyv- és Lapkiadó Kft., Bratislava

Buček, M. (1999): Regional disparities in transition in the Slovak Republic. European Urban and Regional Studies, 4., 360-364.

Džupinová, E., Halás, M., Horňák, M., Hurbánek, P., Káčerová, M., Michniak, D., Ondoš, S., Rochovská, A. (2008): Periférnost' a priestorová polarizácia na území Slovenska. Geografika, Bratislava

http://www.upsvar.sk/statistiky/nezamestnanost-mesacne-statistiky (Letöltés: 2016. február 21.)

http://www.statistics.sk/pls/elisw/casovy_Rad.procDlg (Letöltés: 2015. november 4.)

http://ujszo.com/online/kozelet/2013/07/12/januartol-az-alapsegelyt-is-le-kell-dolgozni (Letöltés: 2016. január 28.)

Juríćková, V., Košta, J. (1995): Dlhodobá nezamestnanost̉ a jej sociálne dôsledky v Slovenskej republike. Sociológia, 1-2., 45-49.

Klamár, R. (2011): Vývoj regionálnych disparít na Slovensku s osobitným zretel’om na regióny východného Slovenska. Acta Facultatis Studiorum Humanitatis et Naturae Universitatis Prešoviensis. Folia Geographica, 18., 89-170.

Kornai J. (2005): Közép-Kelet-Európa nagy átalakulása - siker és csalódás. Közgazdasági Szemle, december, 907-936.

Lelkes G. (2008): Magyarok Szlovákiában. V. kötet. Régiók és gazdaság. Fórum Kisebbségkutató Intézet, Somorja 
Machová, R., Tóbiás Kosár Sz., Bálintová, M. (2014): Iparfejlődési sajátosságok Kelet-Szlovákiában. Selye János Egyetem Gazdaságtudományi Kar, Komárom

Matlovič, R., Matlovičová, K. (2011): Regionálne disparity a ich riešenie na Slovensku v rozličných kontextoch. Acta Facultatis studiorum humanitatis et naturae Universitatis Prešoviensis. Folia Geographica, 18., 8-88.

Mezei I., Hardi T. (2003): A szlovák közigazgatás és területi fejlődés aszimmetriái. Tér és Társadalom, 4., 127-155.

Mihalík, J., Ackerman, K. F., Tyson, S., Thiery, H., Borkovska, S. (1994): Trh práce a sociálne dôsledky ekonomickej reformy v Slovenskej republike. Bradlo a.s., Bratislava

Morvay, K. (szerk.) (2005): Transformácia ekonomiky. Ústav slovenskej a svetovej ekonomiky slovenskej akadémia vied, Bratislava

Nižňanský, V., Reptová, O. (szerk.) (1999): Od spoločného k súkromnému. M.E.S.A., Bratislava

Rajčáková, E., Švecová, A. (2009): Regionálne disparity na Slovensku. Geographia Cassoviensis, 2., 142-149.

Reiter F., Semsey I., Tóth A. (2004): Kelet-Szlovákia régió gazdasági átalakulása. In: Átalakuló régiók. Dél-Szlovákia és a magyarok által lakott régiók gazdasági helyzete. Európai Összehasonlító Kisebbségkutatások Közalapítvány. Budapest, 41-55. (Mủhelytanulmány; 10.)

Rievajová, E., Krausová, A. (1996): Problematika dlhodobej nezamestnanosti v Slovenskej republike. Friedrich Ebert Stiftung, Bratislava

Rievajová, E., Pongráczová, E. (2007): Trendy vývoja na slovenskom trhu práce a výzvy pre 21. storočie. Katedra Socialneho Rozvoja a Prace, Bratislava

Tř́ska, D. (2002): Kupónová privatizace. Centrum pro ekonomiku a politiku, Praha 